\title{
PENERAPAN MODEL PEMBELAJARAN KOOPERATIF TIPE NUMBERED HEAD TOGETHER (NHT) TERHADAP HASIL BELAJAR MATEMATIKA DAN KEPERCAYAAN DIRI SISWA SMP
}

\author{
Mardiati \\ STKIP Budidaya Binjai
}

\begin{abstract}
ABSTRAK
Penelitian ini bertujuan untuk mengetahui apakah terdapat pengaruh model pembelajaran Kooperatif Tipe Numbered Head Together (NHT) terhadap hasil belajar matematika dan kepercayaan diri siswa SMP. Jenis penelitian ini adalah penelitian eksperimen semu (quasi eksperiment) dengan desain penelitian pretestposttest control group. Populasi dalam penelitian ini adalah seluruh siswa kelas VII SMP Budi Utomo Binjai, sedangkan sampel dalam penelitian ini terdiri dari dua kelas yaitu masing-masing berjumlah 32 siswa. Metode penelitian yang digunakan adalah menggunakan metode campuran (mixed method) dengan model penggabungan kuantitatif dan kualitatif. Analisis data kuantitatif dalam penelitian ini dengan menggunakan analisis regresi dan analisis data kualitatif menggunakan analisis deskriptif. Hasil statistika deskriptif, rata-rata hasil belajar matematika kelas pembelajaran NHT adalah 61,844 dan kelas pembelajaran langsung adalah 61,175. Dari data postes diperoleh persamaan regrsei adalah $\mathrm{Y}=16,76+0,803 \mathrm{X}$. Berdasarkan hasil uji analisis regresi diperoleh $\mathrm{r}=0,839$ artinya terdapat hubungan yang positif antara model pembelajaran terhadap hasil belajar matematika, dengan nilai pengaruhnya sebesar $70,05 \%$. Untuk tingkat kepercayaan diri siswa diperoleh data siswa pada kelas NHT yang memiliki tingkat kepercayaan diri tinggi yaitu sebanyak 56,25\% dan tingkat kepercayaan diri cukup yaitu sebanyak 43,75\%. Sedangkan pada kelas langsung tidak ada siswa yang memiliki tingkat kepercayaan diri tinggi, siswa hanya memiliki tingkat kepercayaan diri cukup yaitu sebanyak $87,5 \%$ dan tingkat kepercayaan diri rendah yaitu sebanyak $12,5 \%$. Jadi, penggunaan model Pembelajaran kooperatif tipe NHT (Numbered Heads Together) berpengaruh positif dan signifikan terhadap hasil belajar matematika dan kepercayaan diri siswa SMP.

Kata kunci : Numbered Head Together (NHT), Hasil Belajar, Kepercayaan Diri.
\end{abstract}

\section{PENDAHULUAN}

Pendidikan memegang peranan penting dalam mempersiapkan sumber daya manusia bagi kehidupan di masa yang akan datang. Pendidikan merupakan usaha manusia agar dapat mengembangkan potensi dirinya, antara lain melalui proses pembelajaran di sekolah, baik Sekolah Dasar (SD), Sekolah Menengah Pertama (SMP), Sekolah Menengah Umum (SMU), maupun Sekolah Menengah Kejuruan (SMK), serta Perguruan Tinggi (PT), yang masing-masing memiliki visi, misi dan tujuan yang spesifik. Dunia pendidikan pun semakin dituntut untuk lebih memberikan kontribusi yang nyata dalam upaya meningkatkan kemajuan bangsa.

Untuk meningkatkan mutu pendidikanjuga memerlukan proses belajar mengajar variasi. Variasi dalam proses belajar mengajar ditunjukkan oleh seorang guru dengan adanya perubahan dalam gayamengajar, variasi media yang digunakan dan adanya perubahan dalam pola interaksi antara guru dengan siswa, siswa dengan guru dan siswa dengan siswa. Proses belajar mengajar tersebut meliputi beberapa mata pelajaran yang penting pada umumnya termasuk matematika.Matematika merupakan ilmu universal yang mempunyai peran penting dalam berbagai disiplin ilmu dan berperan besar dalam perkembangan teknologi informasi dan komunikasi yang kian pesat. Seperti yang diungkapkan oleh Hujodo bahwa: "Matematika 
adalah suatu alat mengembangkan cara berfikir. Karena itu matematika diperlukan untuk kehidupan seharihari maupun dalam menghadapi kemajuan ilmu pengetahuan dan teknologi sehingga matematika perlu dibekalkan kepada setiap peserta didik sejak SD, bahkan sejak TK".

Matematika juga merupakan ilmu yang membekali siswa berfikir logis, analistis, sistematis, kritis, kreatif dan kemampuan bekerja sama secara efektif. Sikap dan cara berfikir seperti ini dapat dikembangkan melalui proses pembelajaran matematika, karena matematika mempunyai struktur dan keterkaitan yang kuat dan jelas antara konsepnya sehingga memungkinkan siapapun yang mempelajarinya terampil berfikir rasional. Oleh karena itu, sangat pantas bila matematika dijadikan sebagai salah satu mata pelajaran yang diajarkan mulai dari tingkat dasar, menengah, sampai perguruan tinggi.

Namun pada kenyataannya, kualitas pendidikan di Indonesia yang masih jauh lebih rendah dari negara-negara lain, hal ini dikuatkan hasil penilain internasional tentang prestasi siswa. "Survei Trends International Mathematics and Science Study (TIMSS) pada tahun 2015 menempatkan Indonesia pada perolehan rerata skor Matematika 397 poin, berada pada rangking 45 dari 50 negara”. Hasil TIMSS Indonesia yang rendah tersebut tentunya disebabkan oleh banyak faktor. Salah satu faktor penyebabnya antara lain siswa di Indonesia pada umumnya kurang terlatih dalam menyelesaikan soal-soal.

Rendahnya hasil belajar matematika siswa dikarenakan pembelajaran matematika yang dilakukan secara monoton yang mengakibatkan siswa tidak belajar secara aktif sehingga berdampak pada hasil belajar siswa yang kurang memuaskan.Memang, tidak sepenuhnya faktor rendahnya hasil belajar siswa adalah guru dan metode pembelajaran. Selain guru dan metode pembelajaran yang merupakan faktor dari luar siswa, ada faktor lain yang dapat mempengaruhi hasil belajar siswa, yaitu faktor yang berasal dari dalam diri siswa. Djamarah mengatakan bahwa: "Beberapa faktor yang dapat mempengaruhi proses dan hasil belajar diantaranya faktor lingkungan, faktor instrumental, kondisi fisiologis, dan kondisi psikologis."

Selain hasil belajar siswa, dalam pembelajaran matematika terdapat aspek psikologi yang harus diperhatikan. Salah satu aspek tersebut adalah Self Confidence atau kepercayaan diri. Masih banyak siswa yang memiliki kepercayaan diri yang rendah.Ketika siswa diberikan pertanyaan oleh guru, siswa menjawab dengan tidak yakin atau ragu-ragu. Dengan adanya rasa percaya diri, siswa akan lebih termotivasi untuk menyelesaikan soal-soal yang menuntut percaya atas kemampuan pada diri sendiri. Mengingat pentingnya meningkatkan kepercayaan diri pada siswa secara utuh, maka siswa membutuhkan bantuan orang tua dan guru. James Neill menyatakan bahwa : "Self Confidence adalah keyakinan terhadap penilaian atas kemampuan diri dan merasakan adanya 'kepantasan' untuk berhasil”.

Indikator Self Confidence adalah: (1) Percaya pada kemampuan sendiri; (2) bertindak mandiri dalam mengambil keputusan; (3) memiliki konsep diri yang positif; (4) berani mengemukakan pendapat.

Kepercayaan diri tidak hanya harus dimiliki oleh orang dewasa, tetapi anak-anak juga memerlukannya dalam perkembangannya menjadi dewasa. Kepercayaan diri sulit dikatakan secara nyata, tetapi kemungkinan besar orang yang percaya diri akan bisa menerima dirinya sendiri, siap menerima 
tantangan dalam arti mau mencoba sesuatu yang baru walaupun ia sadar bahwa kemungkinan salah pasti ada. Orang memiliki kepercayaan diri dapat menyelesaikan tugas atau pekerjaan yang sesuai dengan tahapan perkembangan dengan baik atau setidaknya memiliki kemampuan untuk belajar cara-cara menyelesaikan tugas tersebut, sehingga dapat menumbuhkan keberanian dan kemampuan untuk meningkatkan prestasinya sendiri.

Dengan permasalahan di atas solusi yang dapat dilakukan dengan menerapkan metode pembelajaran yang aktif, salah satunya melalui metode Cooperative Learning tipe Number head together (NHT). Model pembelajaran kooperatif tipe Number head together (NHT) berupaya membantu siswa untuk meningkatkan kepercayaan diri dan keterampilan mempelajari materi untuk mencapai hasil belajar yang optimal. David dan Roger Johnson dan rekan-rekan sejawatnya (Johnson et al,1979 dan Johnson \& Johnson,2006) telah mengeksplorasi bagaimana lingkungan kelas yang kooperatif dapat melahirkan pembelajaran yang lebih baik dan pandangan yang lebih positif terhadap siswa-siswa dengan kebutuhan khusus yang dimasukkanke dalam kelas-kelas regular terhadap banyak siswa lainnya.

Informasi dari Guru matematika SMP Budi Utomo Binjai, berkaitandengan pembelajaran matematika di kelas VII terungkap berbagai masalah. Salah satu permasalahan yang dialami siswa sesuai dengan tes awal yang peneliti lakukan yaitu rendahnya hasil belajar dan siswa menjawab dengan tidak yakin atau ragu-ragu.

Salah satu model pembelajaran yang tepat untuk meningkatkan hasil belajar dan kepercayaan diri siswa adalah model pembelajaran kooperatif tipe Number head together.Pembelajaran kooperatif tipe NHT merupakan salah satu tipe pembelajaran kooperatif yang menekankan pada struktur khusus yang dirancang untuk memengaruhi pola interaksi siswa untuk meningkatkan penguasaan akademik.Tujuan dari NHT adalah memberikan kesempatan kepada siswa untuk saling berbagi gagasan dan mempertimbangkan jawaban yang paling tepat. Kelebihan dari NHT adalah sebagai berikut: setiap siswa dapat mempersiapkan materi sebelum pembelajaran, dapat melakukan diskusi dengan sungguh-sungguh, siswa yang pandai dapat mengajari siswa yang kurang pandai, terjadi interaksi secara intens antar siswa dalam menjawab soal, tidak ada siswa yang mendominasi dalam kelompok karena ada nomor yang membatasi.

Dengan menggunakan model kooperatif, diharapkan siswa termotivasi untuk belajar dan dapat memberikan pengaruh terhadap hasil belajar siswa serta membagikan ide-ide dalam mempertimbangkan jawaban yang paling tepat.Selain itu teknik ini juga mendorong siswa untuk meningkatkan kerjasama mereka.Sehingga dapat melatih siswa untuk belajar berkolaborasi dan kerjasama dalam kelompok. Untuk itu peneliti ingin menggunakan metode pembelajaran Number head together (NHT) yang kiranya dapat membuat siswa untuk lebih menggunakan pengetahuannya sendiri dalam menyelesaikan soal dan kepercayaan diri. 
Materi yang dipilih peneliti adalah bentuk bilangan pecahan yang materinya banyak berkaitan dengan kehidupan nyata. Dalam materi ini, banyak bentuk pecahan dan cara penyelesaiannya yang harus dikuasai oleh peserta didik untuk diaplikasikan dalam kehidupan sehari-hari.

Penelitian terkait dengan pembelajaran kooperatif tipe Number head together (NHT) dan kepercayaan diri salah satunya penelitian yang dilakukan Ubaidillah. Model pembelajaran ini menunjukkan ada pengaruh positif dan signifikanantara model pembelajaran yang digunakan dengan hasil belajar.

Berdasarkan uraian di atas permasalahan yang akan diungkap adalah "Apakah terdapat pengaruh model pembelajaran kooperatif tipe numbered head together (NHT) terhadap hasil belajar matematika dan kepercayaan diri siswa kelas VII SMP Budi Utomo Binjai tahun pelajaran 2018/2019?”

\section{METODE}

Penelitian ini dilakukan di SMP Budi Utomo Binjai yang beralamat di Jl. Dr. Wahidin No.48 Sumber Mulyorejo Binjai Timur, Kota Binjai,Provinsi Sumatera Utara dan dilaksanakan pada semester ganjil tahun pelajaran 2018/2019.

Populasi dalam penelitian ini adalah seluruh siswa kelas VII SMP Budi Utomo Binjai, sampel diambil sebanyak dua kelas yaitu kelas VII-A sebagai kelas eksperimen dengan menggunakan model pembelajaran kooperatif tipe numbered head together (NHT)dan kelas VII-C sebagai kelas kontroldengan menggunakan pembelajaran konvensional.Teknik pengambilan sampling yang digunakan adalah Cluster Random Sampling. Jenis penelitian yang digunakan dalam penelitian ini adalah quasi experimen. Desain penelitian yang digunakan adalah pretest-posttest control group design. perlakuan yang diberikan yaitu model pembelajaran kooperatif tipe numbered head together (NHT) pada kelas eksperimen sedangkan kelas kontrol diberikan pembelajaran langsung.

Tes yang digunakan dalam penelitian ini adalah tes tertulis berbentuk uraian dan non tes berupa skala kepercayaan diri. Untuk data kuantitatif menggunakan Teknik analisis regresi untuk mengetahui pengaruh model pembelajaran kooperatif tipe numbered head together (NHT) terhadap hasil belajar matematika siswa dan kepercayaan diri siswa. Sementara untuk data kualitatif menggunakan analisis statistic deskripsi.

\section{HASIL DAN PEMBAHASAN}

Sebelum melaksanakan pembelajaran pada kedua kelas dengan pembelajaran yang berbeda yakni dengan model pembelajaran kooperatif tipe numbered head together (NHT) dan model pembelajaran konvensional, terlebih dahulu diadakan pretes untuk mengetahui kemampuan awal siswa khususnya hasil belajar matematika siswa dari kedua kelas tersebut.

\section{Data Pretes Hasil Belajar Matematika Siswa Kelas NHT dan Kelas Langsung}

Sebelum melaksanakan pembelajaran pada kedua kelas dengan pembelajaran yang berbeda yakni dengan model pembelajaran kooperatif tipe numbered head together (NHT) dan model pembelajaran langsung, terlebih dahulu diadakan pretest untuk mengetahui kemampuan awal siswa khususnya hasil belajar 
matematika siswa dari kedua kelas tersebut. Dari hasil perhitungan pretes hasil belajar matematika siswa diperoleh nilai rata-rata 58,25 dengan nilai varians dan simpangan baku pada kelas NHT 162 dan 12,73. Sedangkan pada kelas pembelajaran langsung adalah diperoleh nilai rata-rata 57,75, varians 188,32 dan simpangan baku adalah 13,72.

\section{Data Posttes Hasil Belajar Matematika Kelas NHT dan Kelas Langsung}

Setelah diberikan pretes pada kedua kelas, selanjutnya dilakukan pembelajaran yang berbeda yakni dikelas eksperimen dengan model pembelajaran kooperatif tipe NHT dan model pembelajaran langsung di kelas kontrol.

Dari hasil perhitungan pretes hasil belajar matematika siswa diperoleh nilai rata-rata 61,844 dengan nilai varians dan simpangan baku pada kelas NHT 116,52 dan 10,795. Sedangkan pada kelas pembelajaran langsung adalah diperoleh nilai rata-rata 61,1875 , varians 127,855 dan simpangan baku adalah 11,301

\section{Uji Normalitas dan Homogenitas Data}

Uji normalitas yang digunakan adalah uji Liliefors. Uji Liliefors digunakan untuk mengetahui apakah data berasal dari populasi yang berdistribusi normal atau tidak, dengan ketentuan bahwa data berasal dari populasi yang berdistribusi normal jika memenuhi kriteria $\mathrm{L}_{0}<\mathrm{L}_{\mathrm{t}}$ diukur pada taraf signifikansi dan tingkat kepercayaan tertentu. Adapun hasil uji normalitas pretes adalah sebagai berikut.

\section{Hasil Perhitungan Uji Normalitas Pretes}

\begin{tabular}{|l|c|c|l|}
\hline Kelompok & $\boldsymbol{L}_{\mathbf{0}}$ & $\boldsymbol{L}_{\boldsymbol{t}}$ & Kesimpulan \\
\hline Eksperimen & 0,15045 & 0,1566 & Terima $\mathrm{H}_{0}$ \\
\hline Kontrol & 0,15615 & 0,1566 & Terima $\mathrm{H}_{0}$ \\
\hline
\end{tabular}

Dapat disimpulkan bahwa kelas eksperimen diperoleh $(0,15045<0,1566)$ sedangkan pada kelas kontrol $(0,15615<0,1566)$ karena $\mathrm{L}_{\text {hitung }}<\mathrm{L}_{\text {tabel }}$ maka dapat disimpulkan bahwa data berasal dari sampel yang berdistribusi normal.Adapun hasil uji normalitas postes adalah sebagai berikut.

Hasil Perhitungan Uji Normalitas Postes

\begin{tabular}{|l|c|c|l|}
\hline Kelompok & $\boldsymbol{L}_{\mathbf{0}}$ & $\boldsymbol{L}_{\boldsymbol{t}}$ & Kesimpulan \\
\hline Eksperimen & 0,1433 & 0,1566 & Terima $\mathrm{H}_{0}$ \\
\hline Kontrol & 0,1514 & 0,1566 & Terima $\mathrm{H}_{0}$ \\
\hline
\end{tabular}

Dapat disimpulkan bahwa kelas eksperimen diperoleh $(0,1433<0,1566)$ sedangkan pada kelas kontrol $(0,1514<0,1566)$ karena $\mathrm{L}_{\text {hitung }}<\mathrm{L}_{\text {tabel }}$ maka dapat disimpulkan bahwa data berasal dari sampel yang berdistribusi normal.

\section{Hasil Perhitungan Uji Homogenitas Pretes}

\begin{tabular}{|l|l|l|l|}
\hline Kelompok & $\boldsymbol{F}_{\text {hitung }}$ & $\boldsymbol{F}_{\text {tabel }}$ & Kesimpulan \\
\cline { 1 - 1 } Eksperimen & 0,8602 & 1,8221 & Homogen \\
\hline Kontrol & & & \\
\hline
\end{tabular}


Dapat disimpulkan bahwa hasil perhitungan homogenitas pretes menunjukan populasi penelitian ini homogen. Berdasarkan perhitungan dengan menggunakan uji Fisher diperoleh hasil $\mathrm{F}_{\text {hitung }}$ pada kelas eksperimen adalah 0,8602 sedangkan nilai $F_{\text {tabel }}$ adalah 1,8221. Dengan demikian $F_{\text {hitung }}<F_{\text {tabel }}$ ini berarti $\mathrm{H}_{0}$ tidak ditolak, dengan demikian dapat disimpulkan bahwa populasi homogen.Adapun hasil uji homogenitas postes adalah sebagai berikut.

\section{Hasil Perhitungan Uji Homogenitas Postes}

\begin{tabular}{|l|l|l|l|}
\hline Kelompok & $\boldsymbol{F}_{\text {hitung }}$ & $\boldsymbol{F}_{\text {tabel }}$ & Kesimpulan \\
\hline Eksperimen & \multirow{2}{*}{0,9115} & 1,8221 & Homogen \\
\hline Kontrol & & & \\
\hline
\end{tabular}

Dapat disimpulkan bahwa hasil perhitungan homogenitas postes menunjukan populasi penelitian ini homogen. Berdasarkan perhitungan dengan menggunakan uji Fisher diperoleh hasil $\mathrm{F}_{\text {hitung }}$ pada kelas eksperimen adalah 0,9115 sedangkan nilai $F_{\text {tabel }}$ adalah 1,8221. Dengan demikian $F_{\text {hitung }}<F_{\text {tabel }}$ ini berarti $\mathrm{H}_{0}$ tidak ditolak, dengan demikian dapat disimpulkan bahwa populasi homogen.

\section{Analisis Regresi Model Pembelajaran Kooperatif Tipe Numbered Head Together (NHT)}

Hasil perhitungan dari statistik regresi diperoleh bahwa nilai korelasi (R) untuk data pada kelas eksperimen adalah 0,839 dan koefisien determinasi nya adalah 0,705. Ini berarti bahwa terdapat hubungan yang positif dan signifikan model pembelajaran kooperatif tipe NHT terhadap hasil belajar matematika dengan kontribusi model pembelajaran sebesar 70,05\%.

Dari Hasil anava nilai konstanta (a) diperoleh sebesar 16,757, nilai koefisien regresi (b) sebesar 0,803 dengan nilai t-hitung (to) sebesar 8,468 dan nilai signifikansi p-value 0,0045. Koefisien regresi bernilai positif menunjukkan bahwa arah pengaruhnya positif, artinya semakin baik model pembelajaran yng diterpkan oleh guru maka hasil belajar matematika juga akan semakin baik. Sehingga persamaan regresi: $\mathrm{Y}=$ $16,757+0,803 X$.

Pengujian selanjutnya dilakukan uji regresi linier sederhana. Setelah melakukan uji linieritas dan uji keberatian di kelas eksperimen, dari hasil perhitungan diperoleh harga $F_{\text {hitung }}=71,708$. Dengan taraf signifikan $\propto=0.05$ dan nilai p-value sebesar 0,000. Sehingga dapat dilihat Ho ditolak karena dengan pvalue $0,000<0,05$, sehingga Ha tidak ditolak, artinya ada pengaruh antara model pembelajaran NHT terhadap hasil belajar matematika siswa.

\section{Hasil Deskripsi Kepercayaan Diri Siswa}

Tingkat kepercayaan diri siswa diperoleh data siswa pada kelas NHT yang memiliki tingkat kepercayaan diri tinggi yaitu sebanyak 56,25\% dan tingkat kepercayaan diri cukup yaitu sebanyak 43,75\%. Sedangkan pada kelas langsung tidak ada siswa yang memiliki tingkat kepercayaan diri tinggi, siswa hanya memiliki tingkat kepercayaan diri cukup yaitu sebanyak 87,5\% dan tingkat kepercayaan diri rendah yaitu sebanyak $12,5 \%$. 
Hasil penelitian didapat penemuan terhadap kepercayaan diri pada kelas yang menggunakan model pembelajaran kooperatif tipe NHT meningkat dan lebih baik dibandingkan dikelas pembelajaran langsung. Kepercayaan diri siswa pada kelas NHT terpacu dan termotivasi karena pada tahap pembelajaran kooperatif tipe NHT siswa di dorong untuk menjawab dan memberikan masukkan ide dalam belajar matematika. setiap siswa mempunyai kesempatan yang sama untuk berperan aktif dalam pembelajaran.

Hasil ini sesuai dengan beberapa penelitian yang dilakukan oleh Katherine Her Pratiwi (2013) menyimpulkan bahwa model pembelajaran NHT memberikan prestasi belajar matematika yang lebih baik daripada model pembelajaran langsung, serta penelitian Maheady et al. (2006) yang menyatakan bahwa NHT merupakan pembelajaran yang efisien dan efektif dalam meningkatkan keaktifan dan memperbaiki prestasi.

\section{SIMPULAN}

Berdasarkan hasil pengolahan data dan analisis data diperoleh kesimpulan bahwa:

1) Penggunaan model Pembelajaran kooperatif tipe NHT (Numbered Heads Together) berpengaruh positif dan signifikan terhadap hasil belajar matematika siswa SMP.

2) Penggunaan model Pembelajaran kooperatif tipe NHT (Numbered Heads Together) berpengaruh positif dan signifikan terhadap kepercayaan diri siswa SMP dalam belajar matematika.

\section{REFERENSI}

Afdin Oktaviansa, Wili. Pengaruh Model Pembelajaran NHT (Numbered Head Together) Terhadap Motivasi dan Hasil Belajar Siswa, dalam jurnal Pendidikan Matematika. Vol 2 Nomor 01

Arikunto, Suharsimi. Prosedur Penelitian, Jakarta: Rineka Cipta, 2013

Djamarah, Syaiful Bahri. Psikologi Belajar. Jakrta: Rineka Cipta, 2011

Huda, Miftahul, Model-model pengajaran dan pembelajaran, Yogyakarta: Pustaka Belajar Offset, 2013

Sugiono.Metode Penelitian Pendidikan. Bandung: Alfabeta, 2009 